\title{
Testament Augustyna Wróblewskiego
}

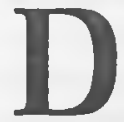

ruk przechowywany w Bibliotece Ossolineum liczy zaledwie dwie strony i jest zapewne jedynym egzemplarzem zachowanym w bibliotekach polskich. Nosi datę 1 września 1913 r., został opublikowany zamiast numeru 6 pisma „Sprawa Robotnicza”. Tytuł, Czarna lista agentów prowokatorów polskich ${ }^{1}$, niedwuznacznie wskazuje na jego demaskatorskie oblicze. W istocie, ów anonimowy tekst zawiera spis domniemanych zdrajców, donosicieli i szpiegów carskiej Ochrany. Kolejnym nazwiskom towarzyszy krótka charakterystyka postaci, czasem motywy, którymi się kierowali, niekiedy tematylka donosów. Anonimowy autor poprzedził listę egzaltowanym prologiem, na poły patriotycznym manifestem, po części ideową cleklaracją. Nad wszystkim unosi się wizja upadku społeczeństwa polskiego, zniszczonego przez pustkę moralną, kryzys wartości, zdradę ideałów. Romantyczne frazy („Naród upadły, spocllały...") sąsiadują z rewolucyjną wizją przemian, idealistycznym obrazom przyszłej wolności i równości społecznej towarzyszy lewicowa retoryka, obficie skąpana we frazeologii proletariackiej rewolty. „Jedna jest droga do zbawienia Polski - czytamy w prologu. - Jest nią droga nowej czarownej wiary, jest nią droga odrodzenia w moralności rewolucyjnej, jest nią droga żywiołowej walki zbratanych mas ludu robotniczego, żołnierzy, chłopów biednych, wszelkich najmitów i całych zastępów rozmaitego upadłego polrrzywdzonego biedactwa. Jest nią droga wszechludzkiego zbratania ludu polskiego $z$ wyzyskiwanemi milionami luclów innych: rosyjskiego, niemieckiego, austryjackiego, przeciw wszelkim władzom, wszelkim rządom, wszelkim posiadaczom i wyzyskiwaczom"2. Także w tym fragmencie splatają się odmienne dyskursy - moralistyczna wykładnia, rewolucyjna fraza, wizja wyzwolenia społecznego w imię braterstwa i solidarności luclów.

W zasadniczej warstwie retoryka tekstu nie wykracza poza formy narracji obecne w manifestach patriotycznych ówczesnych i wcześniejszych lat. Natchnione, idealistyczne formuly, deklaracje o wolności i braterstwie ludu, o rychłej wolności (typu godzina wspólnego wyzwolenia już wybita) inkrustują chociażby tekst styczniowego manifestu powstańczego $z 1863 \mathrm{r}$. Rewolucyjne hasła obecne są zaś w licznych broszurach socjalistycznych, publikowanych w owych latach. Trzy jednak wątki wykraczają poza typowy stereotyp manifestu. Jeden $z$ nich wiąże się $z$ salkralizacją rewolucji. Nieprzypadkowo pojawia się w tekście ów zwrot o „zbawieniu Polski”, autor bowiem dokonuje konsekracji buntu, społecznej rewolty jako swoistej nowej religii. Drugi motyw nawiązuje do anarchistycznych ideałów, wizji wyzwolonych społeczeństw (narodów) spod opresji państw i rządów. Wezwanie do buntu, do powstania „przeciw wszelkim władzom" sięga jednoznacznie ku anarchistycznym korzeniom. Trzeci wątek ma osobisty charakter. W epilogu tekstu obecne są ślady osobistego dramatu, skrajnej desperacji, ale też obsesyjnej wiary w posłannictwo, misję, którą autor ma 
do spełnienia. W rewolucyjnej gorączce pragnie bowiem złożyć najwyższą ofiarę, która zainicjuje rewolucję. „Nie boimy się ich zemsty! - czytamy w zakończeniu tekstu - Temu, kto tę listę wypisal, śmierć jest upragnioną. Oddał on całe życie i całą wartość swej śmierci dla rewolucyi międzynarodowej. Chwila jego śmierci będzie chwilą rozpoczęcia rewolucyi. On nie boi się zepsucia swej opinii i potępienia przez ogół, bo dawno już stoi sam jeden, jako siła czysta rozwoju, przeciw ścigającemu go w szalonej nienawiści i prześladującemu go dla wyzyskania - podłemu motłochowi uprzywilejowanych inteligentów polskich"3. Romantyczna poza nie pojawia się przypadkowo - autor wielokrotnie sięga po romantyczne rekwizyty, jawi się przecież jako buntownilk i prometeista, gotów do najwyższej ofiary w imię wyzwolenia społecznego i przywołanego już „zbawienia Polski". Samotny, opuszczony przez wszystkich podejmuje walkę o najwyższą stawkę.

Czarna lista... jest dokumentem niezwykłym, przede wszystkin za sjprawą dramatycznej zawartości, skrajnej desperacji autora, rozpaczy, która przenika ów tekst, a także, a może przede wszystkim, trudnej do oszacowania dawki szaleństwa. Autor tekstu, Augustyn Wróblewski żegnał się tym tekstem ze współczesnymi. Była to jego ostatnia publikacja, opublikowana po dramatycznym wyjeździe $z$ Polski do Paryża. Zarzut choroby psychicznej, podejrzenie psychozy ścigało go od bez mala 11 lat.

Wyrastał w rodzinie o patriotycznych tradycjach. Wśród jego antenatów spotkamy Maurycego Beniowskiego, żołnierza i podróżnika, konfederata barskiego i zclobywcę Madlagaskaru oraz Bartłomieja Beniowskiego, dziadka Augustyna, majora wojsk polskich w czasie powstania listopadowego. Stryj, Walery Wróblewski, powstaniec styczniowy, wznosił barykady Komuny Paryskiej. Ojciec, Eustachy, lekarz homeopata, spędził jako zesłaniec osiem lat na Syberii. Patriotyczna, niepodległościowa atmosfera domu rodzinnego z jednej, kult nauki $z$ drugiej strony, ukształtowały drogę życiową i zawodową autora Czarnej listy... Imperatyw pracy patriotycznej, udziału w konspiracji, tak oczywisty $w$ tej rodzinie, stał się jednym $z$ powodów, ale i stygmatów dramatycznych losów Augustyna Wróblewskiego. Już w wieku 20 lat, jesienią 1886 r. zostal relegowany ze studiów na Politechnice w Petersburgu za udzial w rozruchach studenckich ${ }^{4}$. Tajny nadzór policyjny będzie mu towarzyszyć przez szereg następnych lat. Jeszcze w 1897 r, a więc 11 lat później, kancelaria warszawskiego oberpolicmajstra raportowała na podstawie tajnej obserwacji o jego kolejnych poczynaniach ${ }^{5}$.

Od 1887 r. Wróblewski studiował chemię na Politechnice Ryskiej. W lutym 1890 r. został usunięty $z$ uczelni w związku z zarzutem politycznej nieprawomyślności. Wcielony do wojska, odbywał slużbę wojskową na Kaukazie w batalionie zakaspijskim. Po powrocie do Wilna został aresztowany 24 stycznia $1891 \mathrm{r}$. i osadzony w cytadeli wileńskiej. Powodlem zatrzymania było odkrycie w jednym z pomieszczeń Politechniki Ryskiej jego dawnej korespondencji, prowadzonej m.in. z Józefem Piłsudskim ${ }^{6}$. Konsekwentny spiskowiec okazał się lekkomyślnym konspiratorem. Wywieziony do Petersburga, skazany został na sześć miesięcy więzienia. Po opuszczeniu murów wyjechał za granicę, początkowo studiował w Brunszwiku (Braunscheig), a następnie w Bernie, kończąc w 1894 r. $\mathrm{z}$ tytułem doktorskim (magna cum laude) Wydział Filozoficzny tamtejszej Poli- 
techniki. Studiował głównie chemię, w tym chemię fizjologiczną. Po praktyce w szwajcarskich laboratoriach chemicznych powrócił do kraju z zamiarem powołania do życia inspektoratu sanitarnego (pracowni chemiczno-sanitarnej) w Wilnie, nie zdołał jednak uzyskać zgody władz miejskich. Wspierany finansowo przez brata, Tadeusza, podjął w r. ak. 1894/95 pracę asystenta Karola Olszewskiego w Zakładzie Chemicznym Uniwersytetu Jagiellońskiego. Przez kolejne dwa lata pełnił funkcję prywatnego asystenta Napoleona Cybulskiego.

Opis wzajemnych relacji obu braci, Augustyna i Tadeusza wymagałby odrębnej rozprawy, w tym miejscu należy odnotować kilka elementarnych faktów. Tadeusz Wróblewski, starszy od Augustyna o sześć lat, wcześniej też przeszedł inicjację konspiracyjną, areszt, osadzenie w Cytadeli i zesłanie w latach 1881-1883 na Syberię. Wówczas jednak, w połowie lat dziewięćdziesiątych, należał już do elitarnego grona wybitnych prawników wileńskich. On też sprawował pieczę nad młodszym, nieustatkowanym, przez niektórych określanym jako „nieobliczalny”, bratem. Bardzo silna zażyłość w miarę upływu lat obrastała w ukryte pretensje, żale, zarzuty. Wyclaje się, iz chwilę przełomową stanowiła tragiczna śmierć w 1890 r. trzeciego, najmłodszego z braci, Kazimierza, cierpiącego przez lata na depresję. Stopniowe rozejście się braci w latach dziewięćdziesiątych nie powstrzymało Tadeusza przed próbami wspomagania Augustyna. Czynił to jawnie, a wobec sprzeciwów brata także w sposób zakamuflowany, jak w przypadku terminowania Augustyna u N. Cybulskiego. Stypendium, które wypłacał Cybulski nieświadomemu rzeczy asystentowi, w rzeczywistości pochodziło od Tadeusza Wróblewskiego ${ }^{7}$.

Od $1894 \mathrm{r}$. A. Wróblewski systematycznie publikował prace naukowe $z$ zakresu biochemii, dzięki którym do dziś uchodzi za jedną z wybitniejszych postaci polskiej biochemii przełomu XIX i XX w. ${ }^{8}$. Dzięki wstawiennictwu brata otrzymał w 1897 r. posadę prowizorycznego inspektora w Zakladzie clo Badania Srodków Spożywczych w Krakowie. Natomiast starania, które poczynił w rok później w celu otwarcia przewodu habilitacyjnego zakończyły się niepowodzeniem. Opinia K. Olszewskiego nie pozostawiała złudzeń - doktorat berneński nie byl poprzedzony systematycznymi studiami chemicznymi, a zatem „uzyskał stopień doktora filozofii na warunkach, na których w Austrii nie mógłby być wcale dopuszczonym do egzaminów doktorskich [...] w pracach zaś p. Wróblewskiego nie ma dostatecznej podstawy do uwolnienia go od cloktoratu" . Olszewski kwestionował zatem zarówno nieregularny tryb studliów Wróblewskiego, jak i jego dorobek naukowy. Czy jedynie względy naukowe zaważyły na odmowie otwarcia przewodu habilitacyjnego? Wydaje się, iz poważną rolę odgrywała niechęć krakowskiego środowiska naukowego wobec osoby znikąd, której na dodlatek niekonwencjonalne zachowanie, ryzykowne poglądy, trudny, konfliktowy charakter i zapewne opinia buntownika budzić musiały sprzeciw konserwatywnej $z$ natury ekipy naukowej.

To czego nie dostrzegal Augustyn w zapale prac naukowych, podkreślał w korespondencji do brata pod koniec 1897 r., Tadeusz: „To ostatnie [przedstawienie rozprawy habilitacyjnej] trochę mię niepokoi, o ile znam stosunki krakowskie, to tam przy otrzymaniu jakiejś posady, albo chociażby honorowej godności w rodzaju prywatnej docentury o wszystkiem decyclują stosunki osobiste. Rachuby na pomoc przyjaciół mogą zawieść, czego najlepszy i najdotkliwszy do- 
wód mamy obydwaj na prof. Cybulskim”. I dodawał „Otóż jestem niespokojny, bo wiem, że masz ludzi clla siebie niechętnych (a w tej liczbie ważny w kwestyi habilitacyjnej głos prof. Olszewskiego), a nie wiem czy jest ktoś co Ci zyczliwie i z dobrą chęcią i dobrą wiarą poprze Twe zabiegi, a przytem ktoś, czyjego głosu mogą posłuchać w Krakowie"10. Tadeusz trafnie przewidział zatem tę pierwszą $z$ serii porażek Augustyna Wróblewskiego. Mimo wzrastającej niechęci otoczenia prowadził on nadal badania naukowe, systematycznie publikował, uczęszczał na wykłady zarówno na Wszechnicy Krakowskiej, jak i Uniwersytecie w Zürichu. Tam też oraz w Lipsku prowadził doświadczenia w laboratoriach chemicznych. Dzięlii niezwykłej alktywności naukowej i niejako wbrew otoczeniu (recenzja dorobku naukowego przygotowana przez Cybulskiego zawierała nader powściągliwe oceny) zdołał doprowadzić do egzaminu habilitacyjnego w czerwcu 1901 r. Otrzymał veniam legendi z zakresu chemii biologicznej wraz z tytułem docenta prywatnego. Komisja pod kierunkiem K. Olszewskiego miala także zdecyclować o przyznaniu mu prawa prowadzenia wylkadów uniwersyteckich na Uniwersytecie Jagiellońskim.

Nie sposób dziś rozstrzygnąć w jakim stopniu narastający konflikt $z$ otoczeniem wynikał $z$ cech charakterologicznych Wróblewskiego, w jakim natomiast był skutkiem wrogiej postawy jego współpracowników. Do kulminacji doszło w pierwszych dniach stycznia 1902 r., kiedly to Leon Marchlewski (brat nieslawnej pamięci Juliana), od marca $1900 \mathrm{r}$ : starszy inspektor w Państwowym Zakładzie Badania Środków Spożywczych, w trakcie posiedzenia pracowników zakładu stwierdził, i $\dot{z}$ „Wróblewski jest ciężarem zakładu, ja nie ufam jego pracom, pracuje gorzej od najmłodszego urzędnika (asystenta) i jeżeli p. Wróblewski $z$ zakładu nie ustapi, to ustapi on sam"11. Upokorzony Wróblewski zażądał zadośćuczynienia. Wobec odmowy złożenia publicznych przeprosin, domagał się od Marchlewskiego salysfakcji z bronią w ręku. Autor potwarzy nie przystał na pojedynek. Sąd honorowy, który rozpatrywał sprawę kontliktu, kierując się m. in. zeznaniami kierownika zakładu, Odo Bujwidla, nie znalazł dowodów potwierdzających prześladlowanie Wróblewskiego. W międzyczasie Marchlewski wycofał się z zarzutów. Syluacja Wróblewskiego w zakładłzie stała się dramatyczna, konflikt z Marchlewskim narastał.

Demony, które ścigały go od pierwszego aresztowania w $1886 \mathrm{r}$. clopadły go ostatecznie w maju 1902 r. Próba obicia Marchlewskiego po kolejnym konflikcie kończy się wezwaniem posiłków, Wróblewski rzuca doniczkami i flaszkami, zamierza się młotkiem na Cybulskiego. Na polecenie tego ostatniego zostaje osadzony w krakowskim szpitalu Św. Łazarza. Pospieszna diagnoza Cybulskiego brzmi: „Ostre obłąkanie”. On też zostaje kuratorem Wróblewskiego. Zakulisowe starania Tadeusza o wywiezienie brata $z$ Krakowa dochodzą do skutku w czerwcu tego roku. Po krótkim pobycie w Warszawie umieszczony zostaje w zakładzie w Tworkach. Brak objawów psychozy nie zapobiegnie długiemu pobytowi Wróblewskiego w zakładzie dla nerwowo chorych. Dziś nie sposób rozstrzygnąć jaki splot okoliczności o tym decydowal - kategoryczny sąd Cybulskiego, jako kuratora, iż jedynym miejscem dla Wróblewskiego są Tworki - brak woli Tadeusza, by uwolnić brata z zakładu - brak osoby, która wzięłaby odpowiedzialność za jego dalsze losy i ewentualną opiekę - czy wreszcie lekarska diagnoza, której nie znamy - zniszczenie archiwum szpitala w czasie I wojny świa- 
towej uniemożliwia wgląd w dokumentację choroby. Brak zdecydowanej woli Tadeusza wypisania brata ze szpitala, mimo zgody lekarzy, ostatecznie ustanowił między nimi mur nie do przebycia. Wówczas, poprzez mur szpitalny, August pisał do brata już wyłącznie oficjalne prośby o wypisanie ze szpitala, rozpoczynające się od formuły „Szanowny Panie Doktorze”. Przypuszczalnie nigdy się już nie spotkali.

Pod koniec 1903 r. Bernard Diamand zaoferował opiekę nad Wróblewskim i wyjazd z nim do Sanatorium w Szwajcarii. W styczniu 1904 r. A. Wróblewski opuścił Tworki i wraz z Diamandem udał się do Zürichu. Wyjazcl definitywnie zamykał etap naukowej kariery Wróblewskiego. Późniejsze publikacje będzie podpisywać już jako były docent Uniwersytetu Jagiellońskiego. Krzywda, rzeczywista czy urojona stanie się jednym $z$ centralnych tematów przyszłej jego publicystyki. Wraz $z$ wyjazdem do Szwajcarii umiera zatem Wróblewski-naukowiec, badacz, biochemik, eksperymentator, obezwładniony przez chorobę, zaszczuty (czy tylko w swoim mniemaniu?) przez otoczenie. Kto powraca ze Szwajcarii w rok później? Żarliwy apostoł odrodzenia duchowego, moralista i etyk, namiętny kuytyk degeneracji spolecznej, rzecznil wyzwolenia jednostki od zgubnych namiętności.

W styczniu 1905 r: podczas zgromadzenia młodzieży akademickiej w Krakowie Augustyn Wróblewski dokonuje publicznej spowiedzi. Ujawnia najbardziej intymne szczegóły $z$ własnego życia, dokonuje na oczach tłumu psychicznej wiwiselicji. Przedstawia mroczny obraz własnych wędrówek po domach publicznych, pokus, namiętności, prób wycofania się i rezygnacji, stałych powrotów do lupanarów, nurzania się w seksualnej rozpuście. Osobista spowiedź grzesznika, który wyznaje przewiny, kaja się przed tłumem przypadkowych obserwatorów, a w konkluzji porzuca drogę hańby, wyzwala $z$ pęt namiętności, służyć miała jako wzór do naśladowania. Wróblewski pojawia się na rynku krakowskim jako apostoł moralnej przemiany, który w świecie upadłych wartości ma do spełnienia heroiczną misję. Telsst wystąpienia umieścił następnie w powołanym przez siebie do życia w czerwcu 1905 r. dwutygodnilku „Czystość”, „poświęconym sprawom zwalczania prostytucji i nierządu” ${ }^{\prime 2}$. Pismo stało się w następnych latach platformą prezentacji programu etycznego Wróblewskiego. To on był siłą sprawczą przedsięwzięcia prasowego, głównym autorem, redaktorem i wydawcą, a ponadto propagatorem idei czystości obyczajów na niezliczonych mityngach, wiecach i prelekcjach. Obok haseł etycznych i prawnych, likwidacji prostytucji, zniesienia reglamentacji, zamknięcia clomów publicznych, „Czystość" kreśliła ascetyczny ideal moralny: czystości obyczajów, całkowitej abstynencji, „wstrzemięźliwości od lubieżności i oddawania się zbytniej zmysłowości", zerwania $z$ rozpustą ${ }^{13}$. Propagowano ideał czystej miłości w miejsce związku zdominowanego przez zmysłowe namiętności oraz imperatyw czystości przedślubnej obojga partnerów. Małżeństwo postrzegane było jako pozbawiony zmysłowości duchowy związek dwojga partnerów, połączonych wspólnymi ideami, wspólną pracą, którzy współżycie seksualne podejmują wyłącznie w celach prokreacyjnych. Małżeństwa, które nie chcą lub nie mogą mieć dzieci, wedle zaleceń pisma, „silą woli ograniczą swe pożądania”. Wróblewski niedwuznacznie propagował wzór ascezy seksualnej, panowania nad namiętnościami, okiełznania seksualności w imię rygorystycznego wzoru etycznego. Wyzwolenie człowieka tożsame było $z$ uwolnieniem się od biologii, poskromieniem sek- 
sualnych potrzeb. Abstynencja seksualna miała być warunkiem zachowania sił witalnych. „Toteż od najdawniejszych czasów - pisze Wróblewski - historia opowiada o mężczyznach władających wybitnemi zdolnościami umysłowemi, którzy dla ochrony tychże usuwali stosunek z kobietą z życia swego i zachowali czerstwość i siłę swego umysłu do późnych lat, jak np. Herbert Spencer"14.

Wraz $z$ upływem lat, niewielkim rezonansem czytelniczym „Czystości”, a wręcz ośmieszaniem publicznym programu pisma, poglądy Wróblewskiego radykalizowały się. Teksty antymilitarystyczne, antywojskowe, pacyfistyczne ściągały represje cenzury, w tym duchu wygłaszane prelekcje wywoływały $z$ kolei interwencje policji. Prasa religijna, wydawałoby się bliska programowi etycznemu pisma, konsekwentnie zwalczała zarówno „Czystość”, jak i Wróblewskiego, który nie krył wszak ateistycznej postawy i manifestował ją tym silniej, im większe gromy spadlały nań ze strony środowisk katolickich. W efekcie przylgnęła doń etykieta „Znanego wolnomularza”, mimo, iż nie raz publicznie dystansował się wobec masonerii ${ }^{15}$. Wzrastający ostracyzm społeczny, zamknięcie $z$ końcem 1909 r. „Czystości” z powodu braku odzewu czytelniczego („Pozostaliśmy sami...” - tymi słowy żegnał się $z$ garstką prenumeratorów) wzmagało jeclynie radykalizm jego poglądów.

Kolejne przedsięwzięcie prasowe, miesięcznik „Przyrodniczy Pogląd na Swiat i Ludzi" nie przetrwał roku. Publikowany w 1912 r. miał w zamyśle Wróblewskiego propagować monizm jako światopogląd, który odrzuca ingerencję boską w naturę wszechświata wraz z dualizmem duszy i ciała człowieka, neguje wiare w siły nadprzyrodzone, życie pośmiertne, zgodnie $z$ poglądami głośnego wówczas biologa i filozofa Ernsta Haeckla. W tekstach pisma towarzyszyła temu absolutyzacja nauki, zwłaszcza nauk empirycznych, wiedzy i praw natury. Doświadczenie przyrodnicze mialo być jedynym źródłem wiedzy i prawcly. Antyreligijna publicystyka sąsiadowała $z$ antywojennymi wezwaniami, hasła międzynarodowej solidarności towarzyszyły antyburżuazyjnym wystapieniom. Cenzura konsekwentnie konfiskowała numery pisma, glównie za antyklerykalne treści. W tymże roku powołał także w Krakowie do życia „Sprawę Robotniczą", w założeniu tygodnik, faktycznie nieregularnie publikowany organ anarchistyczno-syndykalistyczny. Wróblewski jawił się w piśmie jako reprezentant wszystkich prześladowanych i wydziedziczonych. Niedawny apostoł etycznej sanacji odgrywał ostatnią ze swych ról: skrajnego krytyka kapitalizmu, państwa i jego instytucji, proroka wolności jako wartości absolutnej, ale także patrona utopijnej wizji pogodzenia wolności czlowieka i solidarności społecznej, ideału wolnego od nadzoru państwa, wyzwolonego od represji władzy obywatela, który znajduje w sobie motywację do niczym nie skrępowanej pracy, solidarności i braterstwa.

W kulcie anarchistycznych zasad odrzucal wszelkie formy zinstytucjonalizowanych stowarzyszeń, w tym związków zawodowych, dzięki czemu prowokował przeciw sobie także środowiska lewicowe. Kwestionował sens tworzenia zinstytucjonalizowanych partii politycznych, w tym partii socjalistycznej ${ }^{16}$. Spontanicznie tworzone związki zawodowe, niezależne od wszellkich partii, miały rozpocząć akcję bezpośrednią. Swoją przynależność do anarchistów motywował tym, iż nie pozostało mu nic oprócz rozpaczy. Śledzony przez policję, więziony i sądzony, wyjechał z Krakowa w 1913 r., obawiając się powtórnego aresztowa- 
nia ${ }^{17}$. Zatrzymał się w Paryżu, gdzie opublikował dwie ulotki. Pierwsza z nich, Szakale na pobojowisku w świetle wschodzącego słońca, wydlana zaniast nr 5 „Sprawy Robotniczej” nie zachowała się w zbiorach bibliotecznych. Była zapewne pierwszą próbą ostatecznego rozrachunku z przeszłością. Przez socjalistyczny „Naprzód” skwitowana została jako „obłąkany świstek”, w którym „całe społeczeństwo polskie uznane było za społeczeństwo szpiegów, donoszących <telepatycznie> (!!) ochranie warszawskiej"18. Nie sposób dziś zweryfikować tej oceny.

Nieclługo potem ukazała się Czarna lista... Można jej zawartość czytać wyłącznie jako manifestację choroby psychicznej, która ścigała Wróblewskiego od kilkunastu lat. Należy jednak spojrzeć na tekst jako swoisty testament, skrrzywiony i zdeformowany, w skrajnie karykaturalnej formie rodzaj pożegnania z żyącymi, ostateczne przecięcie więzów z wszystkimi bliskimi, którzy zawiedli jego oczekiwania i współpracownikami, którzy pozostawili go na placu boju. I $z$ wrogami. Lista jest definitywnym rozbratem ze współczesnymi, dowodem rozpaczy osamotnionego człowieka, którego ogromne ambicje nie zostały zrealizowane, liczne uzdolnienia, talenty zaprzepaszczone, poglądy wyśmiane lub zlekceważone. Jest także świadectwem ucieczki w chorobę psychiczną człowieka, który nie znalazł oparcia w najblizszych, krzykiem rozpaczy wobec osamotnienia.

Nie oszczędził nikogo. Czarna lista to w znacznej mierze spis clawnych współpracowników, członków rodziny, bliskich mu niegdyś osób, w tym żony i brata. Na łamach listy pojawia się grupa współpracowników sprzed 1902 r., N. Cybulski (,znany byl z przewrotności charakteru i intryg z rozmaitemi stronnictwami. Pisał dla pieniędzy bardzo dużo dla Ochrany o wszelkich sprawach rewolucyjnych, opozycyjnych, kulturalnych, o wszystkiem, czego od niego żądano. Najwięcej pisał o Aug. Wr., którego jest wrogiem otwartym"), L. Marchlewski („egoista i do zbrodni zdolny”), O. Bujwid („hipokryta i karyerowicz”) i K. Olszewski („Egoista skrajny i karyerowicz, skąpiec samotny, bardzo skłonny do zbrodni. Pisał donosy na rewolucyonistów do rządu austryjackiego i rosyjskiego, mianowicie na Aug. Wr., którego jest wrogiem, szczególnie za to, że Augustyn nosi to samo nazwisko, jaką [!] miał dobroczyńca Olszewskiego - Zygmunt"), działacze polityczni, wśród nich J. Piłsudski, R. Dmowski, W. Jodko-Narkiewicz, redaktor "Przedświtu” czy Hieronim Cohn, a także działacze społeczni, jak H. Radlińska czy K. Bujwidowa. Nie oszczędził nawet jednego z ostatnich współpracowników, pomocnika cukierniczego, Kazimierza Czechowskiego („przyjaciel i uczeń Aug. Wr."), który wraz z nim sądzony był w procesie anarchistycznym w Krakowie. Bratu swemu poświęcił typową w tym zestawie notę („znany adwokat w Wilnie [...], działacz społeczny, używający bardzo dobrej sławy. Pisal do władz rosyjskich o wielu sprawach rewolucyjnych i opozycyjnych, pisał i o bracie swoim Aug. Wr., którego jest wrogiem. Pisał dla pieniędzy i kariery") ${ }^{19}$.

$\mathrm{Ci}$, którzy słyszeli o kulisach publikacji uznali, podobnie jak redakcja „Naprzodu", iż mają do czynienia $z$ tworem chorego umysłu. Istniała jedynie obawa, iż nieświadomi rzeczy czytelnicy „Sprawy Robotniczej” mogą potraktować publikację jako autentyczną i wiarygodną listę agentów carskiej Ochrany. Grupa polskich anarchistów-komunistów, z którymi współpracował Augustyn Wróblewski w Paryżu opublikowala oświadczenie, w którym kategorycznie dystansowała się wobec obu ostatnich publikacji, stwierdzając, że wydał je „osobiście 
dr Augustyn Wróblewski po zerwaniu swym z całą grupą, swym własnym nakładem, bez wszelkiej $z$ nami łączności i wiedzy $z$ naszej strony [...] Wszystko to stało się pod wpływem spotęgowanej choroby nerwowej i umysłowej autora, który cierpi na manię prześladowczą i już oddany zostal pod kuratelę lekarzy specyalistów..." ${ }^{20}$. Namawiano w tym duchu także Tadeusza Wróblewskiego, by opublikował na łamach prasy list wyjaśniający kulisy sprawy. „Taka krótka odezwa nie pogłębiająca całego zajścia - pisał Stanisław Patek - i nie nadająca mu poważnego znaczenia, bez powtórzenia zarzutów i wymienionych nazwisk, utrzymana w tonie poważnym, a dla Pana Augustyna, jako chorego, jak najdelikatniejszym, zrobiłaby dobre wrażenie, a niewątpliwie przyczyniłaby się do tego, aby w robotniczej sferze nie posądzano niewinnych $z$ tej sfery ofiar"21. Sprostowanie tego typu nie zostało opublikowane. Tadeusz Wróblewski nie czynił już żadnych starań, by skontaktować się $z$ bratem. Wydaje się, iż wykreślił go ostatecznie $z$ listy osób żyjących.

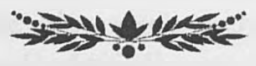

\section{Przypisy:}

${ }^{1}$ A. Wróblewski, Czarna lista agentów prowokatorów polskich, Paryż 1913, s. 1.

${ }^{2}$ Ibidem, s. 1.

${ }^{3}$ Ibidem, s. 2.

${ }^{4}$ Wzią m.in. udział w nielegalnej demonstracji zorganizowanej w rocznice ustawy znoszącej pańszczyznę w Rosji. Por. B. Białokozowicz, Poszukiwania etyczne Augustyna Wróblewskiego i literatura rosyjska, „Acta Polono-Ruthenica”, t. 5, 2000, s. 104. Dodajmy, iż w kilku dostępnych wersjach Curriculum vitae bądź typowego życiorysu, A. Wróblewski starannie omijal fakt studiów w Petersburgu, nie wspominal także o ekspulsji, aresztowaniach i policyjnym śledztwie.

${ }^{5}$ Akta policji wileńskiej w sprawie Augustyna Wróblewskiego. Lietuvos Mokslu Akademijos Biblioteka, Rkps F9 - 1263.

${ }^{6}$ Deateli revolucionnogo dvizenia v Rossii, t. 3.1, Moskva 1933, s. 187.

${ }^{7}$ List N. Cybulskiego do T. Wróblewskiego, [b. d., 1895], Lietuvos Mokslu Akademijos Biblioteka, Rkps F7 - 1034.

${ }^{8}$ Por. I. Z. Siemion, Slawa i zniesławienie: o życiu i pracach Augustyna Wróblewskiego, „Analecta” 2002, z. 1/2, s. 251.

${ }^{9} \mathrm{~K}$. Olszewski, Referat w sprawie udzielenia veniam docendi p. Augustynowi WróbJewskiemu, Archiwum Uniwersytetu Jagiellońskiego, Rkps WF II 121.

${ }^{10}$ List T. Wróblewskiego do A. Wróblewskiego z 21.12.1897 r., Lietuvos Mokslu Akademijos Biblioteka, Rkps F7 - 2003.

${ }^{11}$ Protokót z posiedzenia zastępców w sprawie honorowej pomiędzy p. A. Wróblewskim i p. L. Marchlewskin] [1902], Lietuvos Mokslu Akademijos Biblioteka, Rkps F75 CBA 111.

${ }^{12}$ Początkowo „Czystość” ukazywala się jako dodatek do krakowskiego pisma kobiecego „Nowe Slowo”, redagowanego przez Marię Turzymę. 
${ }^{13}$ Wróblewski byl wydawcą i pierwszym redaktorem „Przyszlości: miesięcznika poświęconego sprawom zupełnej wstrzemięźliwości od napojów alkoholowych”, założonego w 1905 r. w Krakowie. Jego rola w piśmie za sprawą wspólpracowników z wolna malała. Wraz z numerem 9 z 1907 r. opuścił redakcję periodyku.

${ }^{14}$ Potrzeba uświadamiania o istotıym celu małżeństwa, „Czystość” 1906, nr 21, s. 281.

${ }^{15}$ Por. np.: A. Wróblewski, Masoni, „Czystość” 1909, nr 33/34, s. 527-529. Wolnomularzem byl natomiast Tadeusz Wróblewski. Zob. L. Hass, Wolnomularze polscy w kraju i na świecie 1821-1999, Słownik biograficzny, Warszawa 1999, s. 548.

${ }^{16}$ M. Śliwa, Syndykalizm $i$ anarchizm Augustyna Wróblewskiego, „Rocznik Naukowo-Dydaktyczny WSP w Krakowie. Prace Ekonomiczno-Społeczne" 1985, z. 4, s. 30.

${ }^{17}$ Relacja z procesu zob. Dwa procesy anarchistyczne w Krakowie, Kraków 1913.

${ }^{18}$ Wypieraja się obłąkanego, „Naprzód” 1913, n1 211, s. 6.

${ }^{19}$ A. Wróblewski, Czarna lista..., s. 1.

${ }^{20}$ Wypieraja się obląkancgo..., s. 6.

${ }^{21}$ List S. Patka do T. Wróblewskiego z 22.09.1913 r., Lietuvos Mokslı Akademijos Biblioteka Rkps F.7 - 1275. 